\title{
REDISCOVERY OF IMPATIENS MUNNARENSIS BARNES: A STRICT ENDEMIC BALSAM OF SOUTHERN-WESTERN GHATS
}

\author{
R Ramasubbu* and AG Pandurangan ${ }^{1}$ \\ Department of Biology, Gandhigram Rural Institute: Deemed University, \\ Dindigul, Tamil Nadu, India
}

Key words: Impatiens munnarensis, Rediscovery, Western ghats

\begin{abstract}
An endemic wild balsam, Impatiens munnarensis Barnes restricted to Idukki district of Kerala, India has been rediscovered from a new locality Megamalai hills, Tamil Nadu, India after 78 years. The detailed description of the taxa is provided in the presented paper.
\end{abstract}

The Megamalai hill $\left(9^{\circ} 31^{\prime}-9^{\circ} 51^{\prime} \mathrm{N}\right.$ and $\left.77^{\circ} 10^{\prime}-7^{\circ} 30^{\prime} \mathrm{E}\right)$, popularly known as high wavy mountains, a part of the Western ghats is located along the border of Tamil Nadu and Kerala States. The Megamalai hill is bordered by the Periyar Tiger Reserve on the south, Srivilliputtur Grizzled Squirrel Sanctuary on the south and southeast, Cumbam floodplains on the north and north-east and alluvial plains of Theni- Periyakulam on the northeast. A major portion of forests of this area remains unexplored for its biodiversity resources. The natural forest regions of Megamalai was cleared for various commercial plantations like tea, coffee and eucalyptus. Forests of this area have been reported as chief wildlife habitat and recently a division of this forest has been declared as Megamalai Wildlife Sanctuary.

Impatiens munnarensis (Balsaminaceae) was described by Barnes (Fischer 1938) from Top station, Munnar, Idukki District, Kerala, India (Holo Type Barnes 1282, Road side of top station, Munnar, Kerala India on 15.9.1935). After the single collection made by Barnes, no individual specimen has been collected from previous floristic analysis (Ahmedulla and Nayar 1986, Nayar and Sastry 1990) conducted in the type locality of Kerala state by various researchers. The species has been treated under critically endangered category by various reports (Hajra et al. 1997, Bhaskar 2012). During the recent botanical exploration in 2012 to Megamalai hills, Tamil Nadu a plant specimen was collected. After the critical assessment of the specimen by various monographs (Fischer 1938, Ahmedulla and Nayar 1986) and digital herbarium specimens of Royal Botanical Garden, Kew, it has been confirmed as Impatiens munnarensis Barnes. The number of individuals identified in the locality was very poor and the area in which the species distributed was also very less. The previous botanical exploration to the type locality (Top station, Munnar, Kerala) not confirmed the presence of the species. The collected specimens were processed and preserved on herbarium sheet. The voucher specimens were deposited in the Herbarium of Gandhigram Rural Institute: Deemed University, Dindigul, Tamil Nadu, India.

Impatiens munnarensis Barnes in Bull. Misc.. Inform, 32.1938. \& in J. Indian Bot. Soc. 18(3):100. 1939; Sebas. In Bull. Bot. Sur. India 4(1-4): 223.1962; Vevek. et al., Fl. India 4:183.1997; Radhakrishnan et al., Fl. Kerala (ed. Daniel)1: 551.2005; Bhaskar Taxon. Monogr. on Impatiens (Balsaminance) South India 161.2012.

(Fig. 1).

Herbs, weak erect or semi-erect, upto $1 \mathrm{~m}$ height; stems slender, sparingly branched, often procumbent below rooting at lower nodes, leaves variable usually lanceolate, base broadest, shallowly cordate tapering to an acute apex or narrowly ovate, sub-acute at base, distinctly serrate

*Author for correspondence: <racprabha@yahoo.com>. ${ }^{1}$ Plant Systematics and Evolutionary Science Division, Jawaharlal Nehru tropical Botanic Garden and Research Institute, Thiruvananthapuram, Kerala, India. 
along margins with apiculate teeth, setose at base, up to $5.5 \times 1.7 \mathrm{~cm}$, pubescent above, glabrous and pale, sometimes glaucous below; petioles flattened, red above, decurrent on stem; stipules filiform, painted, red, tips darker, bend towards right angles pointing downwards. Pedicels solitary or up to 4, fascicled in axils, very short in bud, in flower $1.0-2.5 \mathrm{~cm}$ long, partially reflexed in fruits. Flowers $1.0-1.3 \mathrm{~cm}$ long. Lateral sepals filiform, curved ca $6 \mathrm{~mm}$ long. Lip boat - shaped, cuspidate in front, white with purple nerves, bottom somewhat flattened with a small pit instead of spur, inside convex continued forward as a ridge with a small yellow or orange crest about middle. Standard ovate, keeled, tip mucronate wings white with lilac or violet markings; distal lobes obovate - triangular; basal lobes triangular; dorsal auricle bluntly conical or rounded placed at right angle, dark purple. Capsules fusiform, later swollen, acuminate, $1.3-1.5 \mathrm{~cm}$ long, a few seeded; seeds black, glossy, ca $1.5 \mathrm{~mm}$ long. Flowering and fruiting: September- January.

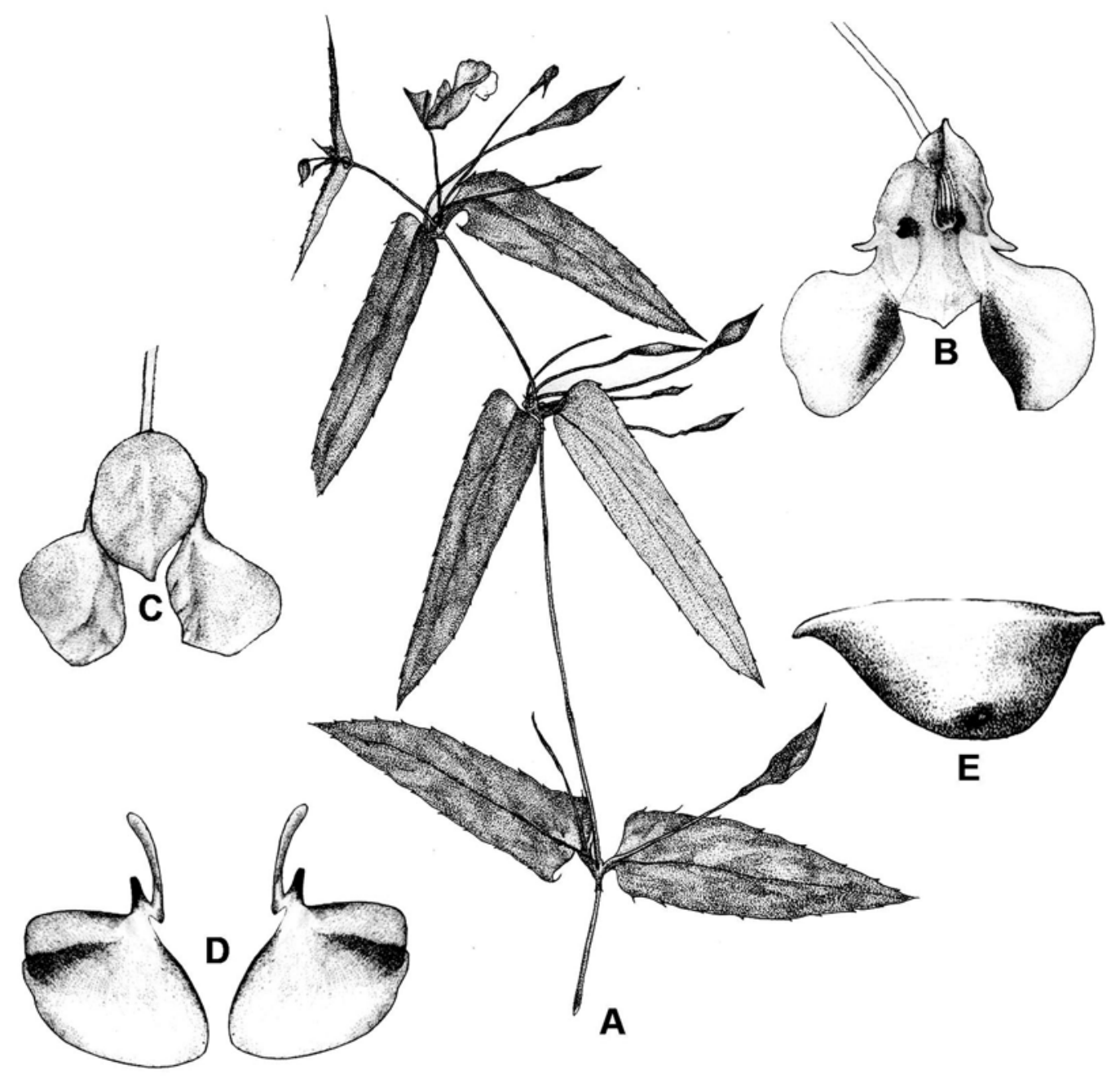

Fig. 1. A. Habit of Impatiens munnarensis, B. Mature flower dorsal view, C. Mature flower ventral view, D. Pair of wing petals, E. Lip (pit marking). 
Specimen examined: India, Tamil Nadu, Varaiaadu motta, High Wavies (Megamalai hills), 1900 m MSL R. Ramasubbu and A. Mohanraj 0208 on 02.09.2012; India, Tamil Nadu, Varaiaadu motta, High Wavies (Megamalai hills), 1900 m MSL R. Ramasubbu and A. Mohanraj 0249 on 25.11.2012.

\section{Acknowledgement}

The authors thank Mr. D. Felix Irudhyaraj for the decisive line drawings of the species.

\section{References}

Ahmedulla MP and Nayar MP 1986. Endemic plants of Indian region. Botanical Survey of India, Culcutta. Bhaskar V 2012. Taxonomic monograph on Genus Impatiens L. Centre for Taxonomic studies, Bangalore. Hajra PK, Nair VJ and Daniel P (eds) 1997. Flora of India, Vol.4. Botanical Survey of India, Culcutta. Fischer CEC 1938. New or little known plants from South India VIII. Kew Bull. 32-37.

Nayar MP and Sastry ARK 1990. Red data book of Indian Plants, vol. 3. Botanical Survey of India, Culcutta. 